\title{
Commercial Risks Arising from Chartering Vessels
}

\author{
Evi Plomaritou ${ }^{1,2}$ and Emmanouil Nikolaidis ${ }^{1,3}$ \\ 1. Lecturer, Frederick University, Cyprus \\ 2. Shipping Consultant, Lloyds Maritime Academy, UK \\ 3. Managing Director, Premium Consulting, Greece
}

\begin{abstract}
This paper constitutes a review of the most important aspects of commercial risks arising from charterparties, operations and claims issues. That means the risks allocated between the shipowner and the charterer throughout the chartering process (pre-fixture, fixture, execution of charter, post-fixture, claims handling), from a financial, operational and legal perspective. The interpretation of the above mentioned matters is considered of critical importance in chartering practice. The analysis is seen from a commercial stand point. Therefore, it is mostly addressed to the shipping practitioners, maritime economists, academics, students and researchers who seek to form a comprehensive view on the subject. It may also form a basis for further study on chartering aspects (legal, economic, managerial and practical).
\end{abstract}

Key words: Chartering practice, chartering policy, commercial risks, charterer, shipowner.

\section{Introduction}

The economic environment in which the shipping industry operates is characterized by high cyclicality, volatility and unpredictability. The market has a high risk profile. The international events (political, economical, technological, social etc.) affect significantly the freight levels and consequently the contractual relationships of shipowners and charterers. The industry is becoming ever more regulated, particularly in areas of safety and pollution. Liability regimes for sea carriers have become more rigorous. As a result, shipowners and charterers face increased exposure to commercial risks. In certain circumstances, these risks are large enough to undermine or destroy the financial base of shipowners and charterers. Successful commercial decisions, chartering policies, management and marketing strategies assist the parties to limit or even to avoid some types of risks [1]. In addition, an increasing number of shipowners and charterers recognize the need to take out insurance protection.

Emphasis should be given on external factors

Corresponding author: Evi Plomaritou, Ph.D., Dr., research field: chartering \& shipping marketing. caused by physical causes and social forces, which affect positively or negatively the charterer's and shipowner's chartering policy, the level of risks that arise and the capacity of the parties to fulfill their responsibilities [2]. Successful commercial decisions and clarity of contracts assist the parties to limit or even to avoid some types of risks.

Physical causes mainly concern physical catastrophes and weather conditions. For example, a heavy winter in Europe will increase the demand for oil, the demand of tankers and consequently it will affect the chartering policy of tanker owners.

Social forces include political, technological and economic events. The term political events is used to refer to such occurrences as localized wars, revolutions, political nationalizations of foreign assets, strikes, canal closures, flag boycotts, embargoes, oil crises, government changes and similar events. The unforeseen political events bring about a sudden and unexpected change in demand for sea transport services and consequently in the charterers' policy.

The technological events are mainly related to the great technological developments in cargo handling methods as well as in navigational practices. 
Technical developments, such as containerization, stimulate investments in new ships. The transition from one technology to another may affect the economics of a shipowner's business and increase his commercial risks. For example, technological developments in shipbuilding may lead to an increase of demand for the new type of vessel and to the decrease of demand for the existing technologically disdained tonnage.

Because shipping is a service business, ship demand depends on several economic factors including price, speed, reliability and security. The aim of the shipper of goods (who may sometimes be also the charterer in a voyage charter) is to obtain better and cheaper transport of goods over the whole distance from origin to destination. Ports play a vital part in the transport process. Automation in cargo handling and investment in specialist terminals have transformed the shipping business. Ports have several important functions, which are crucial to the efficiency of the ships trading between them. Within this framework, the pricing and investment policy of ports plays a decisive role in the speed of charterer's servicing and therefore in the avoidance of risk of delay.

\section{Commercial Risks}

The nature of commercial risks arising from charterparties, operations and claims issues may be [3]:

- Financial: At the end of the day, each aspect of chartering results in a financial allocation of risks. There are some risks of purely financial nature, e.g. the risk of hire payment default. However, even the risks of operational or legal nature almost always lead to a financial claim or motive.

- Chartering oriented, operational, navigational and geographical: It comprises all those risks that arise from pure chartering orientation (e.g. wrong chartering policy and strategy), as well as from operational matters of a charter, for example cargo handling, shipowner's delivery of a seaworthy vessel to the charterer, provision of the cargo from the charterer etc. Besides, commercial risks may be of navigational or geographical nature, e.g. navigating in dangerous seas (e.g. piracy areas) or employing the vessel outside the agreed trading limits in a time charter etc.

- Legal: All the risks related to the law of the charter are included in this category. Legal matters may concern and affect the whole process of a charter, comprising the pre-fixture stages of investigation and negotiation of the charter, the fixture stages of drafting and signing the charterparty, the stage of the execution of the charter, the post-fixture stages of the allocation of disbursements and the legal claims that may arise from the charter.

- Ethical: The image and reputation of a company may be radically affected from a charter. Considerable risks of an ethical nature sometimes arise. For example, oil major is at risk of being liable for causing oil pollution when he charters a substandard vessel from a bad ship operator, with a drunkard master on board. Consequently, apart from the financial penalties, he is subject to a huge risk of an ethical nature, as well as his reputation and image being badly tarnished.

Commercial risks from charterparties, operations and claims may arise from the default of [4]:

- Each party on his own: Either party (the shipowner or the charterer) may default in a term of the charterparty and be subject to the respective consequences (financial, reputational, legal, operational). For example, in a voyage charter, if the shipowner's vessel does not arrive at an agreed loading port within the stipulated time of the charterparty due to his own fault, he will be at risk of losing a good freight rate, as long as the charterer has the right to cancel the charter.

- Counterparty: Either party (the shipowner or the charterer) is at risk of counterparty default. A charterparty allocates risks and obligations between the shipowner and the charterer. The shipowner offers a vessel and the charterer agrees to employ it, either in a 
voyage charter or in a form of a period charter. For this service, the charterer respectively pays freight or hire to the owner. Consequently, the owner's major counterparty risk is the charterer's default in payment of freight or hire, whereas the charterer's major counterparty risk is the owner's default in providing the agreed vessel (e.g. a seaworthy vessel in accordance with the agreed specifications etc.).

- Third party: Either party (the shipowner or the charterer) may be at risk due to a fault of a third party. For example, a loss or damage may arise from lawyers' misleading instructions, insurance companies, bunkering companies providing bad quality of fuel etc.

- Each party's agents or servants: Either party (the shipowner or the charterer) has its own agents or servants during a charter, e.g. ship's master, ship's agent in a loading port, a stevedoring company etc. Each party is at risk due to their possible faults, mistakes, actions or negligence. It must be stressed that in various types of charter and for specific persons, the allocation of risks and obligations in respect of parties' agents and servants differs. For example, in a voyage charter, the master is appointed by the owner and is considered his servant, whereas in a bareboat charter he is appointed by the charterer and is the latter's servant.

The risks of shipowner and charterer arise:

- By contract: Principal contractual risks and liabilities arise under the charterparty and bill of lading. Most charterparties are governed by the English common law (which is, then, the "applicable law" of the contract). Given English law's "freedom of contract" jurisprudence, the parties however can lessen the level of liability imposed by these implied undertakings, or exclude them altogether with the aid of contractual stipulations [5]. The stipulations need to be expressed in clear language, since lack of clarity would attract the application of common law implied undertakings to the contract of carriage. In any case the contracting parties are free to negotiate the terms of the charter (with the caveat that the contract cannot be contrary to public policy). Great care must be taken with the wording of the charter. The English courts' approach to the interpretation of commercial contracts is, per Lord Hoffmann to find "the meaning which the document would convey to a reasonable person having all the background knowledge which would reasonably have been available to the parties in the situation in which they were at the time of the contract": Investors Compensation Scheme v West Bromwich Building Society [1997] UKHL 28. His Lordship referred with approval to the approach towards the interpretation of commercial contracts taken by Lord Wilberforce in Prenn v Simmonds [1971] 1 WLR 1381 and Readon Smith Line Ltd v Yngvar Hansen-Tanger [1976] 1 WLRR 989, saying that Lord Wilberforce's views had led to "fundamental change" towards contractual interpretation [6]. Reardon Smith is a landmark contract law case, in which the House of Lords adopted a new approach to the interpretation of contracts, taking the view that the test was not what each party had in mind, but what, against what Lord Wilberforce called "the matrix of the facts", each ought reasonably to have assumed from the language and conduct of the other. The "background knowledge" to which Lord Hoffmann referred in Investors was, he said, that which Lord Wilberforce had considered as the "matrix of fact" about the negotiations and intention of the contracting parties, and would include "absolutely anything which would have affected the way in which the language of the document would have been understood by a reasonable man". Lord Hoffmann's speech in the Investors case is often referred to as the "Restatement of Contracts".

- Under the Hague Rules: Although the Hague, Hague Visby nor Hamburg Rules apply on a mandatory basis to charterparties, nearly all charterparties will incorporate an express Hague clause. Generally it is the Hague Rules which are preferred in charters to the Hague Visby Rules as they have the lower limitation. An important difference 
between the two regimes in respect of the incorporation of the Hague Rules into charters is that Hague Rules do not have the third party limitation provision: Art IV bis. This is why charters will also have a third party limitation clause, otherwise known as a Himalaya clause [7].

- By statute: Various risks and liabilities arise by statutes, such as fines, customs, penalties and regulations instituted by the international maritime organisations [8]. For example, from the beginning of the 1990s special emphasis was given worldwide to safety and pollution prevention. This brought about the institution and application of new stricter regulations, mainly from IMO (e.g. ISPS Code 2004), from American legislation (e.g. OPA 90) and from the European Union (modification of the international agreement MARPOL subsequent to the marine accident of Prestige in 2002), with the consequence of creating implications in ship operation and management as well as in chartering policies of charterers and shipowners. Penalties and costs imposed in respect of pollution and environmental damage have increased in recent years. Shipowners must comply with the safety rules in order to hold their position in the shipping market.

- In tort: Tort is a civil wrongful act, wilful or negligent, other than a breach of contract, where this act causes injury to another person, or damage to a person's property, reputation or commercial interests [9]. It can also arise without "fault" on the wrongdoer, by strict liability. The injured party is entitled to compensation. For example, a form of such type of liability may concern that to third parties such as personal injury to stevedores caused by the negligence of the shipowner, charterer or their employees. It is worth mentioning that compensation levels for death and injury have increased considerably nowadays. Liability for personal injury and death can never be excluded under English law: s 2(1) of the Unfair Contract Terms Act 1977 does not allow the exclusion of such liability, and in this respect, the Act forms part of the mandatory law of the forum.

\section{Interests at Commercial Risk}

The interests that are at commercial risk from charterparties, operations and claims may include the following:

- The vessel: During a charter the vessel may be delayed, damaged or even get lost.

- The cargo: The same applies to the cargo.

- The income (freight / hire / demurrage / claims/ disbursements): All forms of income are always in danger. Payment depends on shipowner's fulfillment of his obligations in accordance with the charterparty and on the credibility of the counterparty (charterer).

- The bunkers: A ship's damage or loss may lead to a loss of bunkers, for which settlement must be made between the parties.

- Third parties: Third parties may be harmed during the execution of a charterparty. For example, damage in a berth caused by a ship's bad operation, or an injured stevedore due to charterers' fault. Liability against third parties is typically covered by the P \& I insurance.

- The environment: The threat of oil pollution always forms a significant risk for the parties. Considerable amounts of compensation may be required to be paid to the involved parties. Liability against environmental damage is also typically covered by the P \& I insurance.

- Reputation and image: The image and reputation of the shipowner or charterer can be radically affected by risks in a charter. Each party has its own "track record", follows its own business principles which should be in line with the commonly accepted business ethics and has its own credibility which is widely known by everyone within the shipping market [10].

In general, from charterparties, operations and claims issues, it may be said that the following are the most significant commercial risks to be aware of:

- The market risk: Every part of the shipping 
industry is always moving around the spot freight market of the vessels. All major shipping decisions (buying a second-hand ship or putting an order for a newbuilding, chartering spot or period charters, evaluation of alternative charters, selling or scrapping a vessel etc.) are directly based and affected by the prevailing conditions of the charter market and the future expectations of the involved parties. For example, if a shipowner fixes his vessel for a three-year time charterparty at USD10,000/day and during that time the average earnings of the respective spot market climbs at USD30,000/day, the shipowner will suffer huge losses.

- The risk of timing at decision-making: The same decision (e.g. chartering vessels at spot market) may be right at a specific point of time, whilst it may be wrong at another. The charter market is highly volatile and cyclical. So, perfect timing of decisions is the initial key of success.

- The chartering strategy and policy risk: The selected chartering strategy and policy of a company determines the amount of risk undertaken. When chartering a vessel, some important aspects that one must take into account are [11]:

- Should we charter spot, taking the whole risk of high volatility of the spot market? In other words, should we take on by ourselves all the potential upside but also all the downside risk of the market?

- Should we put the vessel in some form of period charter (time charter, bareboat), in such case fixing our future earnings, but taking the risk of losing the upside potential of the spot market?

- Who is the counterparty? Is he credible? What is his track record and reputation? The longer the charter, the more important these questions become.

- What is the market forecast? What are our expectations? What is our character, mentality, temperament and psychology?

- When is the perfect timing for a decision?

- What are the available chartering alternatives at a specific point of time and at a specific geographical location?

- Should we hedge or insure some chartering risks?

- The currency risk: The currency of the charterparty puts a significant risk on the involved parties. Most charterparties provide that freight or hire payment is to be made in US dollars. When earnings of a party are denominated in a different currency than the costs and expenses are, then a currency exchange risk exists. Taking into account that the exchange rate of some currencies may have high volatility, this risk may sometimes be considerable.

- The bunkers risk: Nowadays, cost of bunkers may even form $60 \%$ of a ship's total cost. In a voyage charter, such cost is borne by the shipowner, whereas in a time or a bareboat charter the charterer is responsible. It is self-explanatory how critical bunker prices may be in parallel with the selected type of charter. Besides, bunkers risk may have qualitative aspects. The optimum choice of a bunkering company ensures the good quality of fuel for the ship in order to avoid a damaged engine. The geographical optimization of bunkering in order to avoid deviations is also crucial for chartering purposes. Moreover, the optimization of bunkers quantity in relation to the carried cargo quantity is always of paramount importance. Finally, a ship's damage or loss may lead to bunkers' loss, for which settlement must be made between the parties in accordance with the facts of the case.

- The risk of loss: Vessel, cargo, bunkers and income may be lost, in full or in part, as a result from the risk allocation between the parties, the execution of the charter, shipping operations and claims disputes.

- The risk of damage: Similarly, vessel and cargo may be damaged.

- The risk of delay: It is a considerable aspect of commercial risk. Vessel and cargo may be delayed during a charter. The risk and cost of such delay are allocated between the contracting parties [12].

- The risk of death or injury: Shipping 
operations are extremely tough and may sometimes cause the death or injury of involved persons (e.g. crewmen, stevedores).

- The freight risk: It is the risk which lies with the owner when he, fully or partly, fails to fulfill his obligation to carry the cargo and thereby lose his right to collect freight, in full or in part respectively.

- The credit risk: It is the shipowner's counterparty risk. It concerns the risk of charterer's default in payment of freight or hire.

- The interest rates risk, the inflation risk and the opportunity cost risk: A charter agreement concerns a commitment of capital in the shipping business. Therefore, such risks should not get underestimated when a vessel is chartered.

\section{Commercial Risks during the Stages of Chartering Process}

Commercial risks, as described above, may be encountered during all stages of the chartering process (pre-fixture, fixture, execution of charter, post-fixture, claims handling), namely:

- Investigation for a charter.

- Evaluation of charter alternatives (voyage estimation).

- Negotiation between the parties.

- Fixture of the charter (recap).

- Charterparty construction/drafting and signature.

- Execution of the charter: In a voyage charter, there are the following stages of a voyage:

- Preliminary (ballast) voyage of the ship to the loading port;

- Loading operation;

- Carrying (laden) voyage from loading to discharging port;

- Unloading (discharging) operation;

- Delivery of cargo to the bill of lading holder (cargo receiver/consignee).

- Claims and dispute resolution: There are the following means/stages of dispute resolution where commercial risks may further arise:
- Negotiation;

- Mediation;

- Arbitration;

- Litigation.

\section{Mitigation of Commercial Risks}

Commercial risks arising from charterparties, operations and claims could be faced and mitigated by some of the following methods:

- Insurance: Involved parties may be insured against most of the commercial risks, such as loss or damage of vessel or cargo, loss of income (freight, hire, demurrage etc), loss of bunkers, personal injury or death, oil pollution, ship's collision, ship's trading in war areas, liability against third parties etc.

- Hedging: Shipping derivative products may be used to mitigate various commercial risks. The most important shipping instruments are called FFAs (Forward Freight Agreements) and are those which help the parties be secured (hedged) against the freight market risk. Moreover, similar derivative products exist to secure against the bunker price fluctuation risk, the currency exchange risk and the interest rate risk [13].

- Forecasting: In the era of globalization and internet, every shipping practitioner should be fully aware of the developments. An accurate forecast of the future always helps in taking the right decision at the right time, eliminating commercial risks.

- Marketing strategy and chartering policy optimization: Market risk may be restricted by an optimum marketing strategy and chartering policy of a company [14]. For example, a shipowning company which follows a customer retention policy as part of a complete and fully developed marketing strategy, is more likely to find employment for its vessels, therefore eliminating the risk of them being idle in a depressed freight market. Furthermore, a typical example of market risk mitigation is a shipowner who prefers to fix his vessel in a long-term charter with a first class charterer and satisfactory daily rate, 
therefore "locking" his future income but losing the upside potential of the spot market.

- Chartering process optimization: Commercial risks may be limited by the optimization of the whole chartering process (pre-fixture, fixture, execution of charter, post-fixture, claims handling). For example, following the standard code of business ethics during negotiations, carefully drafting the charterparty clauses, cooperating with trustworthy partners, making business with credible counterparties, employing competent "servants" (e.g. crews) and agents, having reliable legal support, insurance cover and financial advisors, are only some of the ideas which may result in a chartering process optimization system.

- Salvage: It might be said that the "salvage principle" constitutes the last resort for limiting the risk of losing a property at sea (e.g. vessel, cargo, bunkers). A vessel in danger can be saved, either by another commercial ship or by an expert salvage company, and if the salvage is successful then the salvor has the right to get a financial compensation for that. Salvage is widely based on the "no cure, no pay principle". That means, if salvage is not successful, no reward is given to the salvor. Salvage is typically covered from ship's insurances: H \& M (Hull \& Machinery) insurance and P \& I (Protection \& Indemnity) insurance. Salvage is only presented for reference. It is not an actual way of proactively mitigating the commercial risk.

\section{Conclusion}

This is a synopsis about the allocation of risks between the shipowner and the charterer throughout the chartering process (pre-fixture, fixture, execution of charter, post-fixture, claims handling), from a financial, operational and legal perspective. In respect of the commercial risks from charterparties, operations and claims issues it may be said that:

- Risks and liabilities of shipowner and charterer arise: (i) by contract, (ii) by statute, and (iii) in tort.

- The nature of commercial risks may be: (i) financial, (ii) chartering oriented, operational, navigational or geographical, (iii) legal, and (iv) ethical.

- Commercial risks may arise from the default of: (i) each party on their own, (ii) counterparty, (iii) third party, and (iv) each party's agents or servants.

- The interests that are at commercial risk are: the vessel, the cargo, the income, the bunkers, third parties, the environment, and the reputation and image of shipowners and charterers.

- The most significant commercial risks highlighted are: the market risk, the risk of timing in decision making, the chartering strategy and policy risk, the currency risk, the bunkers risk, the risk of loss, the risk of damage, the risk of delay, the risk of death or injury, the credit risk, the interest rates risk, the inflation risk and the opportunity cost risk.

- Commercial risks may be encountered during all stages of the chartering process (pre-fixture, fixture, execution of charter, post-fixture, claims handling).

- Commercial risks may be mitigated by some of the following helpful methods, tools and ideas: (i) insurance, (ii) hedging, (iii) forecasting, (iv) marketing strategy and chartering policy optimization, and (v) chartering process optimization.

\section{References}

[1] Plomaritou, E., Plomaritou, V., and Giziakis, K. 2011. "Shipping Marketing and Customer Orientation: The Psychology \& Buying Behaviour of Charterer \& Shipper in Tramp and Liner Market." Journal of Management 16 (1): 57-89.

[2] Plomaritou, E. 2008. Marketing of Shipping Companies: A Tool for Improvement of Chartering Policy. Athens: Stamoulis Publications, ICS Recommendation, 52-6.

[3] Plomaritou, E. 2016. Commercial Risks Arising from Charterparties, Operations and Claims Issues. London: Lloyds Maritime Academy, 20-1.

[4] Plomaritou, E. 2015. Charterparty Contracts. London: Lloyds Maritime Academy, 28-30.

[5] Carr, I. 2010. International Trade Law. 4th ed. New York: Routledge-Cavendish, 161-2, 173-4, 207.

[6] http://www.bailii.org/uk/cases/UKHL/1997/28.html (accessed 15 June 2016).

[7] Baughen, S. 2015. Shipping Law. 6th ed. Routledge-Cavendish, 78-9, 94.

[8] Sheppard-Mandaraka, A. 2009. Modern Maritime Law 
and Risk Management. 2nd ed. London: Informa, 76, 136, 306, 390, 911.

[9] Wilson, J. F. 2010. Carriage of Goods by Sea. 7th ed. London: Pearson Education Ltd.

[10] Goulielmos, A., and Plomaritou, E. 2009. "A Review of Marketing in Tramp Shipping." International Journal of Shipping and Transport Logistics 1 (2): 119-55.

[11] Plomaritou, E. 2014. Chartering Policy \& Marketing Strategy of Shipping Companies. London: Lloyds
Maritime Academy.

[12] Zarate, J. A. F. 2009. "Risk of Delay in Charterparties: Like a Ping-Pong Game?" Revista E-Mercatoria 8 (1).

[13] http://www.mercatusenergy.com/blog/bid/81549/A-Begin ners-Guide-to-Fuel-Hedging-Futures.

[14] Plomaritou, E., and Goulielmos, A. 2014. "The Shipping Marketing Strategies within the Framework of Complexity Theory." British Journal of Economics, Management \& Trade 7 (4): 1128-42. 